\title{
REVIEW \\ Mary C. Boys \\ Redeeming our Sacred Story: \\ The Death of Jesus and Relations \\ between Jews and Christians
}

(New York: Paulist Press, 2013), paperback, xii +387

Marianne Moyaert,

VU University Amsterdam / Katholieke Universiteit Leuven

Mary Boys' book focuses on the New Testament accounts of the crucifixion of Jesus and their interpretation by later Christians. She shows that while these sacred stories have been liberating to Christians, they have been put to "sacrilegious" use against Jews (p. 47). Throughout Christian history the passion narratives that constitute the heart of Christian identity have been used to rationalize and legitimize violence against the Jewish people. It is well-known that for centuries Good Friday was the most dangerous day for Jews living in Europe. The accusation, especially, that the Jews are responsible for the death of Jesus has been at the core of Christian antiJudaism and has had catastrophic consequences for them. Boys argues that Christians must acquaint themselves with these dark pages in their history, take responsibility for it, and reread (and thereby redeem) the passion narratives in a constructive way. This book is a historical and exegetical study interwoven with important and nuanced theological reflections and insights.

Boys develops her argument in three parts. In the first, "A Trembling Telling," Boys shows how the New Testament accounts of Jesus' passion have caused Christians to "tremble" at their power (p. 3). All too often, however, these accounts have been told in a problematic fashion. While the focus of Boys' book is on Jewish-Christian relations, in the first part of her study she broadens the scope to show that the passion 
narratives have been criticized from various perspectives. She gives voice to feminist and womanist theologians as well as to black liberationist theologians not only to uncover how these stories have been wrongly told (chapter 1), but also to bring forth the liberating possibilities in these stories (chapter 2).

This twofold dynamic of deconstruction and reconstruction is mirrored in the next two parts of her book. In the second, "A Troubling Telling-and Its Tragic Consequences," Boys narrows her scope, again focusing on Jewish-Christian relations and how "the New Testament, so beloved and vital to Christianity, includes texts that have provided the raw materials for harsh depictions of Jews as enemies of Christ" (p. 47). For it to be possible to "redeem our sacred stories," Christians must be willing to look directly at the violent history that has resulted from these troubling tellings. This is precisely what Boys does in the following chapters. Her historical analysis reveals how over the course of centuries Jews were charged with deicide, and how this charge prompted anti-Jewish violence. In chapter three, she studies the four gospels, Acts, and the letters of Paul, and shows that the New Testament already contains the "raw materials accusing Jews" of the death of Jesus (pp. 47-75). In the next chapter, she surveys early Christian apocryphal texts and writings from the Middle Ages (noting the tragic shift that began with the Crusades). Boys shows how anti-Jewish prejudices grew stronger and stronger in this period until they shaped a general view of Jews as less than human. An original anti-Jewish pattern of thought that first served Christian identity-formation (a binary division of "us" and "them") was deepened during the Middle Ages, as seen in devotional literature that highlighted Christ's passion and intensified Jewish guilt. The Jewish people were cast as demonic for their responsibility in shedding the innocent blood of Christ.

In the fifth chapter, Boys moves from the medieval into the modern period and argues that hatred against the Jews intensified even further due to a merging of Christian anti-Judaism and racial antisemitism. Even though the accusation of deicide continued to be made, it was presented differently in different 
periods and contexts, and its impact on the Jews also varied. During the Enlightenment, such anti-Judaism was intertwined with the so-called "Jewish Question" that asked "whether Jews could be integrated in the nation" (p. 138). In this modern period, she also considers whether Nazi antisemitism is continuous or discontinuous with Christian anti-Judaism (chapter 6). Though Boys affirms that the linkage is undeniable-Christian anti-Judaism and racial antisemitism intersect, even to such an extent that ordinary believers may not have noticed the difference-Boys also notes the discontinuities.

In the third part of her study, "A Transformed Telling," Boys, drawing on biblical scholarship, reads the troubling texts differently. She focuses her attention on central claims of biblical scholars that contribute to a new interpretation of the passion narratives. In chapter 7 , she brings into focus how the crucifixion of Christ has to be understood against the background of the Roman Empire, which she depicts as an empire that relied on violence and terror. She argues that it is most likely that the ruling parties (both the Roman procurator Pilate and the Jewish chief priests) were responsible for the death of Christ. Based on historical evidence, it cannot be said that the entire Jewish people pressed for the death of Christ. In chapter 8, Boys turns to Paul, who has often been depicted as someone who strongly opposed Judaism and its legal tradition. Drawing on insights from the so-called "New Perspective on Paul," she argues that Paul was a Jesus-believing Jew who did not relinquish his Jewish identity, and whose gospel was directed especially against the Roman imperial order. For him, Christ is Lord, not Caesar.

This claim brings Boys to her next point. While we think of Judaism and Christianity as two different religions, we should not forget that the so-called "parting of the ways" was a slow process that took almost four centuries and occurred at a different pace in different contexts. When reading the New Testament narratives of Christ's passion and especially the role of "the Jews" in these events, it is important to realize that there existed no such thing as Judaism and Christianity. It is 
better to speak about Jesus-believing Jews, non-Jesus believing Jews, and gentiles who were following Jesus' "way." The boundaries between these different groups were not clearly fixed for a long time.

In the last two chapters of her study, Boys formulates several concrete interpretative strategies that will enable Christian readers today to redeem their sacred stories. She applies these when exploring the possibilities of transformed and transformative readings of the passion of Christ. She applies her rereadings to traditional devotional practices such as the Ignatian "Spiritual Exercises" and the "Seven Last Words." Considering these traditional practices, Boys shows how Christ's cross may become a "tree of life for the healing of the Nations" (p. 228).

This book would be an excellent choice for a course on Jewish-Christian relations. I intend to make it required reading when I teach such a course next year. 